\title{
KINERJA GURU SMK PROGRAM KEAHLIAN TEKNIK BANGUNAN DI DAERAH ISTIMEWA YOGYAKARTA
}

\author{
Wahyu Purwaning Warastuti \\ SMKN 1 Sayegan Sleman \\ adhemanis@gmail.com \\ Husaini Usman \\ Universitas Negeri Yogyakarta \\ husainiusman@gmail.com
}

\begin{abstract}
Abstrak
Penelitian ini bertujuan untuk mengetahui kinerja guru SMK sebagai pendidik, pengajar, pembimbing, pengarah, pelatih, penilai dan pengevaluasi pada program keahlian Teknik Bangunan di DIY. Penelitian ini merupakan penelitian deskriptif kuantitatif dengan variabel kinerja guru dan subvariabel: pendidik, pengajar, pembimbing, pengarah, pelatih, penilai, dan pengevaluasi. Populasi pada penelitian ini adalah para guru SMK Negeri di Daerah Istimewa Yogyakarta untuk kompetensi keahlian teknik bangunan sejumlah 115 orang. Pengumpulan data menggunakan angket tertutup dengan 4 pilihan jawaban yang dijaring melalui pendapat para guru. Uji coba validasi instrumen dilakukan dengan analisis butir dan reliabilitas dihitung menggunakan formula Alpha dari Cronbach. Hasil penelitian menunjukkan kinerja guru SMK program keahlian Teknik Bangunan di DIY secara keseluruhan memiliki tingkat kinerja yang cukup tinggi. Rerata kinerja guru secara keseluruhan 74.09 dengan rentang skor $26-104$. Kinerja guru sebagai pendidik memiliki tingkat kinerja yang tinggi, sebagai pengajar memiliki tingkat kinerja cukup tinggi, sebagai pembimbing memiliki tingkat kinerja cukup tinggi, sebagai pengarah memiliki tingkat kinerja yang tinggi, sebagai pelatih memiliki tingkat kinerja cukup tinggi, sebagai penilai memiliki tingkat kinerja cukup tinggi dan sebagai pengevaluasi memiliki tingkat kinerja cukup tinggi.
\end{abstract}

Kata kunci: kinerja, guru, SMK, teknik bangunan

\section{THE TEACHING PERFORMANCE OF THE VOCATIONAL HIGH SCHOOLS TEACHERS, DEPARTMENT OF CIVIL ENGINEERING IN YOGYAKARTA SPECIAL TERRITORY (DIY)}

\begin{abstract}
The Objective of this research is to know the teaching performance of the teachers of Civil Engineering department in DIY as educator, and teacher, and guide, and director, and coach, and assesor, and evaluator.This was descriptive quantitative research by using teacher's performance as the variable and subvariables of teacher, instructoxr, guide, director, coach, assesor and evaluator. The populations of the study were 115 teachers of vocational high school in DIY. The teacher have expertise civil engineering. The data were collected by using closed question-naire with four respose choices given to the teachers. The validity of the instrumen was measured through item analysis, while the reability was measured by using Alpha Cronbach Formula.The results of the research show that the teaching performance of vocational school that the teaching performance of vocational school teachers of civil engineering departement in DIY totally have high criterion. The teaching performance was high criterion, teacher's performance as an educator was have high criterion, teacher's performance as a guide was have high criterion, teacher's performance as a director was high criterion, teacher's performance as a coach was have high criterion, teacher's performance as an assesor was have high criterion, teacher's performance as an evaluator was have criterion.
\end{abstract}

Keywords: performance, teacher, vocational high school, civil engineering 


\section{PENDAHULUAN}

Memasuki era globalisasi, dunia pendidikan Indonesia saat ini dan di masa mendatang menghadapi tantangan yang semakin berat dan kompleks. Indonesia harus mampu bersaing dengan negara-negara lain, baik dalam produk, pelayanan, maupun dalam penyiapan sumber daya manusia. Upaya peningkatan kualitas Sumber Daya Manusia (SDM) melalui pendidikan dan pelatihan harus terus dikembangkan sesuai dengan tuntutan pasar kerja baik untuk skala lokal, nasional, regional maupun internasional. Menurut Tim Yayasan Pengembangan Pendidikan dan Telematika Indonesia (YPPTI) dalam http://yppti.org (2010), hal ini ditandai dengan; (1) struktur tenaga kerja Indonesia masih didominasi oleh pekerja yang kurang terdidik sehingga tidak banyak berpengaruh terhadap peningkatan pertumbuhan ekonomi; (2) penguasaan kompetensi dan produktivitas tenaga kerja Indonesia masih rendah dibandingkan dengan tenaga kerja negara-negara lainnya di kawasan Asia Tenggara. Semua ini menyebabkan tenaga kerja Indonesia sulit bersaing, bahkan tidak sedikit peluang pekerjaan yang ada di Indonesia diisi oleh pekerja asing. Ketersediaan sumber daya yang berkualitas dan penguasaan ilmu pengetahuan dan teknologi membutuhkan penyelenggaraan pendidikan yang bermutu pada setiap jenjang pendidikan.

Undang-undang Nomor 20 Tahun 2003 tentang Sistem Pendidikan Nasional Pasal 1 menerangkan, "Pendidikan adalah usaha sadar dan terencana untuk mewujudkan suasana belajar dan proses pembelajaran agar peserta didik secara aktif mengembangkan potensi dirinya untuk memiliki kekuatan spiritual keagamaan, pengendalian diri, kepribadian, kecerdasan, akhlak mulia, serta keterampilan yang diperlukan dirinya, masyarakat, bangsa dan negara." Hal ini mengindikasikan bahwa pendidikan berfungsi untuk mengembangkan kemampuan dan membentuk watak serta peradaban bansa yang bermartabat dalam rangka mencerdaskan kehidupan bangsa yang diharapkan dapat mengembangkan potensi peserta didik agar menjadi insan yang taqwa berakhlak, berilmu pengetahuan dan terampil, mandiri serta bertanggung jawab.

Peraturan Pemerintah Republik Indonesia Nomor 74 Tahun 2008 Tentang Guru menyebutkan, "Guru adalah pendidik profe- sional dengan tugas utama mendidik, mengajar, membimbing, mengarahkan, melatih, menilai dan mengevaluasi peserta didik pada pendidikan anak usia dini jalur pendidikan formal, pendidikan dasar, dan pendidikan menengah." Guru adalah kunci utama dalam sistem pendidikan, hal lain dalam dunia pendidikan khususnya sekolah tidak banyak berarti apabila fungsi dasar pembelajaran yaitu interaksi guru dengan peserta didik tidak berkualitas. Demikian pentingnya peran guru sehingga dapat disimpulkan bahwa peningkatan kualitas dan kinerja guru akan sangat berpengaruh terhadap kualitas pendidikan

Maklassa dalam http://www.igi.or.id (2012) mengungkapkan bahwa kualitas pendidikan yang ada di Indonesia dewasa ini masih tertinggal dibandingkan dengan negaranegara di Asssociation of the South East Asia Nation (ASEAN) apalagi dengan negara-negara Eropa. Saat ini kualitas pendidikan Indonesia dianggap masih rendah karena beberapa indikator; (1) lulusan dari sekolah belum siap memasuki dunia kerja karena minimnya kompetensi yang dimiliki, (2) peringkat indeks pengembangan manusia (human development index) masih sangat rendah, (3) mutu akademik di bidang IPA, Matematika masih rendah, (4) penguasaan terhadap iptek masih tertinggal dari negaranegara lain. Indeks Prestasi Kumulatif menunjukkan masih banyak di bawah standar 7.5 dan banyaknya lulusan tidak terserap ke sekolah negeri. Sedangkan kualitas pendidikan yang masih rendah dikarenakan kinerja guru yang rendah dalam meningkatkan kualitas pendidikan.

Perkembangan teknologi dan media pengajaran yang pesat menjadi tututan bagi guru untuk berkembang. Anik Sulistyawati dalam http://www.harianjogja.com (2009) mengatakan kemampuan guru gunakan ICT masih rendah, Kemampuan guru dalam menggunakan sistem information and communication technology (ICT) dinilai rendah. Padahal, pemahaman sistem ini sangat menunjang dalam pembelajaran electronic learning (E-Learning). Media internet cukup familier di kalangan peserta didik saat ini, hampir setiap siswa bisa mendapatkan fasilitas internet dengan mudah baik di lingkungan sekolah atau di luar sekolah. Akan tetapi, kemampuan siswa menguasai aplikasi internet itu tidak dibarengi dengan tingginya kemam- 
puan guru dalam menggunakannya. Padahal, penguasaan aplikasi internet itu sangat menunjang pembelajaran E-Learning di masingmasing sekolah.

Guru dituntut memiliki kinerja yang mampu memberikan dan merealisasikan harapan dan keinginan semua pihak terutama masyarakat umum yang telah mempercayai sekolah dan guru dalam membina anak didik. Dalam meraih mutu pendidikan yang baik sangat dipengaruhi oleh kinerja guru dalam melaksanakan tugasnya sehingga kinerja guru menjadi tuntutan penting untuk mencapai keberhasilan pendidikan. Secara umum mutu pendidikan yang baik menjadi tolok ukur bagi keberhasilan kinerja yang ditunjukkan guru. Berdasarkan Peraturan Pemerintah Republik Indonesia Nomor 74 Tahun 2008 tentang Guru menyebutkan bahwa guru adalah pendidik profesional dengan tugas utama mendidik, mengajar, membimbing, mengarahkan, melatih, menilai dan mengevaluasi peserta didik maka perlu adanya kondisi yang ideal guru berdasarkan tugas pokok yang harus dijalani.

Kesenjangan antara kinerja guru yang terjadi dilapangan dan yang tercantum dalam Peraturan Pemerintah berdasarkan tugas utama guru perlu untuk dicermati secara mendalam. Dengan memahami tugas utama guru dan kinerja guru yang diharapkan maka akan mendorong peningkatan kinerja sebagai sutau sikap dan perilaku yang berkelanjutan

Beberapa permasalahan yang terkait dengan kinerja guru, antara lain :guru belum mempunyai kinerja yang tinggi, beban mengajar guru dirasakan sangat berat dengan jumlah minimal 24 jam mengajar per minggu, kurangnya motivasi guru dalam meningkatkan kinerja, penggunaan metode ceramah yang membosankan serta penilaian kinerja guru berdasarkan tugas pokok dan fungsi guru belum diakomodir. Penelitian ini akan difokuskan penilaian kinerja guru berdasarkan tugas pokok dan fungsi guru SMKN program keahlian teknik bangunan di Daerah Istimewa Yogyakarta pada tahun 2013. Hal ini kami lakukan mengingat: pentingnya mengetahui kinerja guru untuk program keahlian teknik bangunan karena rendahnya minat siswa. Realita dilapangan untuk daerah Istimewa Yogyakarta dari hasil pra survey yang dilakukan di SMKN I Seyegan, dan SMKN 2 Wonosari terdapat variasi kemampuan guru dalam menjalankan tugas pokok dan fungsi guru. Dengan demikian perlu dilakukan penelitian kinerja guru berdasarkan Tugas pokok dan fungsi guru. Penelitian hanya difokuskan untuk Guru yang mengajar pada Program Keahlian Teknik Bangunan, hal ini disebabkan dari sedikitnya minat peserta didik untuk mendaftar pada kompetensi keahlian tersebut dan adanya persepsi bahwa teknik bangunan adalah pilihan terakhir untuk masuk SMK Negeri kelompok teknologi dan rekayasa. Penelitian ini diharapkan dapat mengungkapkan prinsip-prinsip penilaian kinerja guru yang sesuai dengan tugas pokok dan fungsi guru, khususnya guru Kompetensi Keahlian Teknik Bangunan yang ada di Daerah Istimewa Yogyakarta.

Kultur Jawa mendefinisikan guru adalah " $g u$ " dan " $r u$ " yang berarti digugu dan ditiru. Digugu atau dipercaya/dianut, karena guru mempunyai ilmu, memiliki wawasan dan pandangan yang luas dalam melihat kehidupan ini. Ditiru atau di ikuti karena guru mempunyai kepribadian yang utuh, tindakannya patut dijadikan teladan dan contoh bagi peserta didik.

Guru adalah kunci utama dalam sistem pendidikan, hal lain dalam dunia pendidikan khususnya sekolah tidak banyak berarti apabila fungsi dasar pembelajaran yaitu interaksi guru dengan peserta didik tidak berkualitas. Demikian pentingnya peran guru sehingga dapat disimpulkan bahwa peningkatan kualitas dan kinerja guru akan sangat berpengaruh terhadap kualitas pendidikan. Peraturan Pemerintah Republik Indonesia Nomor 74 Tahun 2008 Tentang Guru menyebutkan bahwa "Guru adalah pendidik profesional dengan tugas utama mendidik, mengajar, membimbing, mengarahkan, melatih, menilai dan mengevaluasi peserta didik pada pendidikan anak usia dini jalur pendidikan formal, pendidikan dasar, dan pendidikan menengah. Berdasarkan tugas pokok guru tersebut dapat dipahami bahwa fungsi guru adalah sebagai pendidik, pengajar, pembimbing, pengarah, pelatih, penilai dan evaluasi.

\section{Mendidik dengan Peran Pendidik}

Undang-Undang Nomor 20 tahun 2003 tentang Sistem Pemdidikan Nasional mendefinisikan pendidik adalah tenaga kependidikan yang berkualifikasi sebagai guru, dosen, konselor, pamong belajar, widya- 
iswara, tutor, instruktur, fasilitator, dan sebutan lain yang sesuai dengan kekhususannya, serta berpartisipasi dalam menyelenggarakan pendidikan. Pendidik berasal dari kata 'didik' ditambah awalan 'pe' yang berarti orang yang bertugas mendidik untuk sesuatu yang baru (ilmu/paham/ pengetahuan/ ajaran), dimana peserta didik tersebut tidak memahami sama sekali, sehingga pendidik juga berkewajiban memberi tahu asal ilmu, sebab akibat dan tujuan dari pendidikan yang diberikan. Karena itulah seorang pendidik bertanggung jawab atas hasil yang dicapai anak didiknya termasuk perkembangan dalam menerapkan pengetahuan tersebut, ada nilai pendampingan. Mendidik artinya memelihara dan memberi latihan(ajaran, tuntunan, pimpinan) akhlak dan kecerdasan pikiran.

Mulyasa (2006:37) menyatakan bahwa guru adalah pendidik yang menjadi tokoh, panutan dan identifikasi bagi para peserta didik dan lingkungannya. Sejalan dengan pendapat tersebut Noor Jamaluddin (1978:1) mendefinisikan guru adalah pendidik, yaitu orang dewasa yang bertanggung jawab memberi bimbingan atau bantuan kepada anak didik dalam perkembangan jasmani dan rohaninya agar mencapai kedewasaannya, mampu berdiri sendiri dapat melaksanakan tugasnya sebagai makhluk Allah khalifah di muka bumi, sebagai makhluk sosial dan individu yang sanggup berdiri sendiri. Suryosubroto (1983:26) mendefinisikan bahwa pendidik berarti orang dewasa yang bertanggung jawab memberi pertolongan pada peserta didiknya dalam perkembangan jasmani dan rohaninya, agar mencapai tingkat kedewasaan, mampu berdiri sendiri dan memenuhi tingkat kedewasaannya, mampu mandiri dalam memenuhi tugasnya sebagai hamba dan khalifah Allah swt, dan mampu melaksanakan tugas sebagai makhluk social dan sebagai makhluk individu yang mandiri. Roestiyah(1982:86) mengatakan sesungguhnya seorang pendidik bukanlah bertugas memindahkan atau mentrasfer ilmunya kepada orang lain atau kepada anak didiknya.

Walker (2008:61) mengungkapkan "...led me to formulate twelve identifiable personal and professional characteristics of effective teachers: 1) Prepared 2) Positive 3) Hold High Expectations 4) Creative 5) Fair 6) Display a Personal Touch 7) Cultivate a Sense of Belonging 8) Compassionate 9) Have a Sense of Humor 10) Respect Students 11) Forgiving 12) Admit Mistakes" (...membuat saya merumuskan dua belas identitas pribadi dan karakteristik pendidik profesional yang efektif: 1) Melakukan persiapan 2) Bersikap Positif 3) Mempunyai harapan yang besar 4) Kreatif 5) Cukup Adil 6) Memiliki Sentuhan Pribadi 7) Sense of Belonging 8) Pengasih 9) Memiliki Rasa Humor 10) Menghormati peserta didik 11) Pemaaf 12) Mengakui Kesalahan. Dengan demikian dapat disimpulkan bahwa Pendidik adalah Orang dewasa yang bertanggungjawab untuk mendidik, membantu peserta didik dalam perkembangan jasmani dan rohani untuk mencapai kedewasaan dan mandiri sebagai makhluk individu dan sosial.

\section{Mengajar dengan Peran Pengajar}

Pengajar berasal dari kata "ajar" yang berarti petunjuk yang diberikan kepada orang untuk diketahui (dituruti). Pengajar berasal dari kata 'ajar' ditambah awal 'peng' yang berarti orang yang bertugas mengajar atau memberi pengajaran. Dalam pengertian lebih lanjut, pengajar adalah orang yang bertugas memberi tahu (ajar) cara atau ilmu atau paham atau sesuatu yang baru kepada peserta ajar (peserta didik) atau mendampingi untuk belajar, hingga bisa melaksanakan hal yang baru tersebut. Tyson dan Caroll 1970 dalam Simamora (2009:54) mengatakan "a way working with students ... A process of interaction. The teacher does something to student, the students do something in return" (sebuah proses hubungan timbal balik antara siswa dan guru yang sama-sama aktif melakukan kegiatan). Dengan demikian maka mengajar kegiatan pengkondisian agar terjadi proses mengajar.

Gagne \& Briggs \& Wagner (1992:3) menyatakan, "instruction is a set of event which affect learners in such a way that learning is facilitated" (pengajaran merupakan seperangkat kegiatan yang mempengaruhi siswa sedemikian rupa sehingga mereka merasa terfasilitasi). Maksud dari pernyataan tersebut adalah proses pembelajaran dengan adanya seperangkat tugas memerlukan pemfasilitasan sehingga proses pembelajaran tersebut sesuai dengan tujuan yang ingin dicapai. Aktifitas belajar siswa harus ber-orientasi pada siswa sehingga pengajar bertindak sebagai pemberi fasilitas terjadinya pembelajaran. Berdasarkan uraian diatas dapat di- 
simpulkan bahwa mengajar merupakan upaya yang sengaja dilakukan untuk memberi kemudahan terjadinya proses belajar sesuai dengan tujuan yang ingin dicapai. Mengajar berarti membuat cara agar orang lain lebih mudah memahami hal-hal yang dipelajari. Selain itu pengajar juga harus mengetahui berapa besar kemampuan peserta didik memahami dan mampu menyerap pengetahuan yang telah dilakukan. Sebagai pengajar ia juga membantu perkembangan anak didik untuk dapat menerima, memahami, serta menguasai ilmu pengetahuan. Untuk itu guru hendaknya mampu memotivasi siswa untuk senantiasa belajar dalam berbagai kesempatan. Akhirnya seorang guru akan dapat memainkan peranannya sebagai pengajar dengan baik bila ia menguasai dan mampu melaksanakan keterampilan-keterampilan mengajar.

Guru sebagai pengajar bahkan sebaiknya juga "mengajar yang mendidik", artinya guru bukan hanya mampu merencanakan, melaksanakan dan mengevaluasi pembelajaran, tetapi juga mampu mengembangkan pembelajaran dengan melandasi dan menanamkan nilai-nilai pendidikan (M. Furqon, 2009, 144).

Peraturan Menteri Pendidikan Nasional Republik Indonesia Nomor 41 Tahun 2007 tentang Standar Proses Untuk Satuan Pendidikan Dasar Dan Menengah point Kegiatan pembelajaran bagian b. Inti: Kegiatan inti merupakan proses pembelajaran untuk mencapai kompetensi dasar. Kegiatan pembelajaran dilakukan secara interaktif, inspiratif, menyenangkan, menantang, memotivasi peserta didik untuk berpartisipasi aktif, serta memberikan ruang yang cukup bagi prakarsa, kreativitas, dan kemandirian sesuai dengan bakat, minat, dan perkembangan fisik serta psikologis peserta didik. Kegiatan ini dilakukan melalui proses eksplorasi, elaborasi, dan konfirmasi.

Wong \& Wong (2009:9) mengatakan "the three characteristics of an effective teacher (a) positive expectations, (b) classroom management, (c) lesson mastery"bahwa tiga ciri pengajar efektif yaitu, : (a)Memiliki ekspektasi positif (memiliki harapan yang tinggi) terhadap kesuksesan siswa, (b) Manajer kelas yang andal, (c) Mengetahui cara merancang pelajaran untuk dapat dikuasai siswa. Sedangkan, Gurney (2007:91) mengatakan: "five key factors that provide a foundation for a good teaching: (a)Teacher knowledge, enthusiasm and responsibility for learning, (b)Classroom activities that encourage learning, (c) Assessment activities that encourage learning through experience, (d) Effective feedback that establishes the learning processes in the classroom, (e) Effective interaction between the teacher and the students, creating an environment that respects, encourages and stimulates learning through experience"

(lima faktor pengajaran yang efektif dari lima faktor utama berikut yang memberikan landasan untuk mengajar yang baik: (a) Pengetahuan guru, antusiasme dan tanggung jawab untuk belajar, (b) mendorong kegiatan belajar di kelas, (c) Penilaian kegiatan yang mendorong belajar melalui pengalaman, (d) Efektif umpan balik yang menetapkan proses pembelajaran di kelas, (e) Efektif interaksi antara guru dan siswa, menciptakan lingkungan yang menghormati, mendorong dan merangsang belajar melalui pengalaman.)

Kesimpulan dari teori-teori di atas adalah bahwa pengajar adalah orang yang melakukan serangkaian kegiatan yang disengaja untuk mempermudah penyampaian pengetahuan atau ketrampilan tertentu kepada peserta didik, agar dapat menerima, menanggapi, menguasai dan mengembangkan bahan pelajaran itu secara bersama dengan arah timbal balik terjadinya proses belajar dengan tujuan yang telah dirumuskan menggunakan metode belajar yang terbimbing dan terfasilitasi.

\section{Membimbing dengan Peran Pembimbing}

Pembimbing berasal dari kata bimbing dapat berarti sebagai : menunjukkan, menentukan, mengatur, mengemudikan, memimpin, mengadakan, mengistruksikan, memberi saran, mengatur. Dalam bahasa inggris membimbing berasal dari kata guide/mentoring yang berarti menunjukan, menentukan, mengatur atau mengemudikan/menjalankan, mendampingi.

Mortensen and Schumuller dalam Ahmad Juntika Nurihsan (2006:7) mengemukakan:

"Guidance may be defined as that part of the total educational program that helps 
provide the personal opportunities and specialized staff services by which each individual can develop to the fullest of his abilities and capacities in term of the democratic idea"

(Bimbingan dapat didefinisikan sebagai bagian dari program pendidikan keseluruhan yang membantu memberikan kesempatan pribadi dan layanan staf khusus dimana setiap individu dapat mengembangkan sepenuhnya kemampuan dan kapasitas dalam hal gagasan demokrasi

Muro and Kottman dalam Ahmad Juntika Nurihsan (2006:7) mengatakan bahwa pada dasarnya membimbing merupakan upaya pembimbing untuk membantu mengoptimalkan individu. Bimbingan yang berkembang saat ini adalah bimbingan perkembangan. Visi bimbingan perkembangan bersifat edukatif, pengembangan dan outreach. Edukatif karena titik berat layanan bimbingan dan perkembangan ditekankan pada pencegahan dan pengembangan bukan korektif ataupun terapeutik. Pengembangan karena titik sentral sasaran bimbingan dan perkembangan adalah perkembangan optimal seluruh aspek kepribadian individu dengan upaya pokoknya memberikan kemudahan perkembangan melalui perekayasaan lingkungan. Target populasi layanan bimbingan dan perkembangan tidak hanya terbatas pada individu yang bermasalah tetapi semua individu berkenaan dengan semua aspek kepribadiannya dalam semua konteks kehidupan (masalah, target intervensi, setting, metode dan lama waktu layanan). Teknik-teknik layanan yang digunakan meliputi pertukaran informasi, bermain peran, tutorial dan konseling.

Peraturan Pemerintah Nomor 29 Tahun 1990 tentang Pendidikan Menengah dikemukakan bahwa "Bimbingan merupakan bantuan yang diberikan kepada peserta didik dalam rangka menemukan pribadi, mengenal lingkungan, dan merencanakan masa depan". Guru sebagai pembimbing mempunyai tugas menjaga, mengarahkan, dan membimbing agar siswa tumbuh dan berkembang sesuai dengan potensinya. Dengan demikian agar guru dapat berperan sebagai pembimbing maka guru harus memahami anak didik yang sedang dibimbingnya, misalnya memahami tentang gaya dan kebiasaan belajarnya, memahami potensi dan bakatnya dan guru harus memahami dan terampil dalam merencanakan, baik merencanakan tujuan dan kompetensi yang akan dicapai, maupun merencanakan proses pembelajaran. Proses bimbingan akan dapat dilakukan dengan baik, manakala sebelumnya guru merencanakan hendak dibawa kemana siswanya, apa yang harus dilakukan, dan lain sebagainya.

Sofyan S. Willis (2003:25) mengatakan bahwa perilaku membimbing; adalah perilaku yang memancar dari aspek-aspek kepribadian sebagaimana ditampilkan oleh seorang pembimbing dengan karakteristik-karakteristik sebagai berikut. a. Empati; dapat merasakan apa yang dirasakan murid. b. Attending; ramah, bersahabat, terbuka. c. Supporting-motivating; mendorong, memotivasi. d. Unconditional positive regard; menghargai secara positif tanpa syarat, menerima, toleran (memaafkan apapun keadaannya). e. Genuine; asli, jujur. f. Respect; menghormati diri dan hak-haknya. g. Correct; tepat, jelas, cermat, mudah dimengerti. h. Realistik; menerima kenyataan. i. Cerdas, kreatif, dan menguasai ilmu. j. Berwawasan religius, psikologis, sosiologis, dan budaya. $\mathrm{k}$. Terampil dalam tugas.

Maka dapat disimpulkan bahwa membimbing merupakan proses pemberian bantuan secara sistematis, terorganisir dan berkesinambungan yang diberikan kepada seseorang atau kelompok agar bisa membuat keputusan, memecahkan masalah, dan bisa memahami diri dan lingkungannya sehingga dapat menyesuaikan diri dimana pun ia berada serta dapat mengoptimalkan segala potensi yang dimilikinya.

\section{Mengarahkan dengan Peran Pengarah}

Uno B. Hamzah (2009:23) mengatakan bahwa guru sebagai pengarah pembelajaran hendaknya guru senantiasa berusaha menimbulkan, memelihara, dan meningkatkan motivasi peserta didik untuk belajar. Dalam hubungan ini, guru mempunyai fungsi sebagai motivator dalam keseluruhan kegiatan belajar mengajar. Seorang pengarah berdiri di depan anak dan menekankan tujuan, keinginan, dan kebutuhannya kepada anak. Pengarah memberikan tugas, menentukan persyaratan, dan menilai hasil belajar. Seorang guru dapat mencari keseimbangan antara perannya untuk berada di depan anak, di belakang anak, atau di samping/di antara anak-anak, sesuai dengan ciri khas (karakteristik anak). Untuk anak 
berbakat sebaiknya seorang guru lebih banyak berada di belakang anak daripada di depan anak. Dalam The Teacher As An Organizer (http://www2.honolulu.hawaii.edu) mengatakan guru sebagai pengarah pembelajaran memiliki karakter sebagai berikut:

"1). Not an autocrat. 2). Positive directors in order to function effectively, clarify its purpose and achieve its desired results. 3). Helps the group and the individuals in it to discover, to formulate, and to clarify their own purposes. 4). Delegates and distributes responsibility as widely as possible. 5). Encourages and values initiative. 6). Builds on strengths rather that emphasizing weakness. 7). Fosters self-criticism and self-evaluation within the group. 8). Maintains control, because without control and as controller, and constantly strives to develop within the class its own self-control in terms of its common purpose" (1).

Bukanlah seorang otokrat. 2). Sebagai pengarah positif agar bisa berfungsi efektif, mengklarifikasi tujuan dan mencapai hasil yang diharapkan. 3). Membantu kelompok dan idividu-idividu di dalamnya untuk menemukan, merumuskan, dan menjelaskan tujuan mereka. 4). Membagi dan mewakilkan atau mendelegasikan tanggung jawab seluas luasnya. 5). Mendorong dan menghargai inisiatif. 6). Lebih baik membangun kekuatan daripada menekankan kelemahan. 7). Membangun kritik dan evaluasi diri dalam kelompok. 8). Memelihara kontrol, karena tanpa kontrol dan usaha yang terus menerus dikembangkan di kelas hanya akan mencapaai tujuan yg biasabiasa saja.) Dengan demikian dapat disimpulkan bahwa guru sebagai pengarah bagi peserta didik, harus mampu mengarahkan peserta didik dalam memecahkan permasalahan-permasalahan yang dihadapi, mengarahkan peserta didik dalam mengambil suatu keputusan dan menemukan jati dirinya. Guru juga dituntut untuk mengarahkan peserta didik dalam mengembangkan potensi dirinya, sehingga peserta didik dapat membangun karakter yang baik bagi dirinya dalam menghadapi kehidupan nyata di masyarakat.

\section{Melatih dengan Peran Pelatih}

Pelatih berasal dari kata latih yang merupakan terjemahan dari kata trainer/coach.
Secara sederhana kata ini dapat diartikan sebagai orang yang ikut serta secara partisipatif dengan aktifitas peserta pelatihan, sedangkan melatih, yaitu mengembangkan keterampilan dan skill siswa. Maritje Terok (2010:424) menerangkan sebagai pelatih, seorang guru dan dosen akan berperan untuk mendorong siswa atau mahasiswanya untuk menguasai alat belajar, memotivasi siswa dan mahasiswa untuk bekerja keras dan mencapai prestasi setinggi-tingginya, dan membantu siswa dan mahasiswa menghargai nilai belajar dan pengetahuan. Endang Rini Sukamti (2009:2) menyebutkan para pelatih diharapkan dapat memahami kinerja seorang pelatih, "Ada 4 poin yang harus diketahui pelatih. Yaitu, tahu, mengerti,paham, dan mampu menjadi pelatih". Sedangkan Serene Koh and Neuman (2006:1) mengemukakan dalam Exemplary Elements of Coaching: "(1). Onsite Coaching. (2). Coaching Should Be Balanced and Sustained (3). Good Coaches Don't Dictate (4). Student Outcome Benefits from Strong Interaction with Coaches (5). Provide Descriptive Feedback (6). Match/ Complement Teachers' Behavioral Style (7). Promote Professional Reflection (8). Coaches Must be Well-trained (9). Good Coaching is Collaborative (10). Prioritize”. (1). Pelatihan di tempat, 2). Pelatihan Harus Seimbang dan Berkelanjutan, 3). Pelatih yang baik tidak mendikte, 4). Lulusan mendapatkan manfaat dari interaksi yg kuat dg pelatih, 5). Memberikan Deskriptif pada umpan balik, 6). Menyesuaikan gaya perilaku guru, 7). Mendorong Refleksi Profesional, 8).Pelatih harus terlatih, 9). Pelatihan yg baik harus kolaboratif, 10)Memprioritaskan).

Guru dalam pendidikan kejuruan berperan sebagai pelatih mencakup aspek kognitif, afektif dan psikomotorik. Proses pendidikan dan pembelajaran memerlukan latihan ketrampilan, baik intelektual maupun motorik, sehingga menuntut guru melatih peserta didik dalam pembentukan kompetensi dasar sesuai dengan potensi masing-masing peserta didik, karena tanpa latihan pesert didik tidak akan mampu menunjukkan penguasaan kompetensi dasar dan tidak akan mahir dalam berbagai keterampilan yang dikembangkan sesuai dengan materi standar. Pelatihan yang dilakukan harus juga memperhatikan perbedaan individual peserta didik dan lingkungan. 


\section{Menilai dengan Peran Penilai}

Peraturan Pemerintah Nomor 19 Tahun 2005 tentang Standar Nasional Pendidikan Bab I pasal 1 ayat 17 menyatakan bahwa "penilaian adalah proses pengumpulan dan pengolahan informasi untuk mengukur pencapaian hasil belajar peserta didik". Popham (1995:3) mendefinisikan "Educational assessment is a formal attempt to determine students' status with respect to educational variables of interest" (penilaian atau asesment dalam kontek pendidikan adalah sebuah usaha formal untuk menentukan status siswa berkenaan dengan berbagai kepentingan pendidikan).

Permendiknas Nomor 20 tahun 2007 menjelaskan: Penilaian pendidikan adalah proses pengumpulan dan pengolahan informasi untuk menentukan pencapaian hasil belajar peserta didik. Menurut Permendiknas Nomor 41 tahun 2007 penilaian dilakukan oleh guru terhadap hasil pembelajaran untuk mengukur tingkat pencapaian kompetensi peserta didik, serta digunakan sebagai bahan penyusunan laporan kemajuan hasil belajar, dan memperbaiki proses pembelajaran. Penilaian dilakukan secara konsisten, sistematik, dan terprogram dengan menggunakan tes dan nontes dalam bentuk tertulis atau lisan, pengamatan kinerja, pengukuran sikap, penilaian hasil karya berupa tugas, proyek dan/atau produk, portofolio, dan penilaian diri. Penilaian hasil pembelajaran menggunakan Standar Penilaian Pendidikan dan Panduan Penilaian Kelompok Mata Pelajaran.

Nanang Hanafiah (2009:75) berpendapat, oleh karena penilaian menekankan pada proses pembelajaran, data yang dikumpulkan dari kegiatan nyata yang dikerjakan siswa pada saat melakukan pembelajaran. Kemajuan belajar peserta didik dinilai dari proses, tidak semata dari hasil. Oleh karena itu, penilaian authentic merupakan proses penilaian pengetahuan dan keterampilan (performasi) yang diperoleh siswa di mana penilai tidak hanya guru, tetapi juga teman siswa atau pun orang lain. Tujuan penilaian adalah memberikan masukan informasi secara komprehensif tentang hasil belajar peserta didik, baik dilihat ketika saat kegiatan pembelajaran berlangsung maupun dilihat dari hasil akhirnya, dengan menggunakan berbagai cara penilaian sesuai dengan kompetensi yang diharapkan dapat dicapai peserta didik.
Penilaian merupakan proses menetapkan kualitas hasil belajar, atau proses untuk menentukan tingkat pencapaian tujuan pembelajaran peserta didik. Sebagai suatu proses, penilaian dilaksanakan dengan prinsip-prinsip dan dengan teknik yang sesuai. Penilaian hasil belajar peserta didik pada jenjang pendidikan dasar dan menengah didasarkan pada prinsipprinsip sebagai berikut: sahih, objektif, adil, terpadu, terbuka, menyeluruh dan berkesinambungan, sistematis, beracuan kriteria, akuntabel. Dengan demikian dapat disimpulkan guru sebagai penilai memfungsikan guru untuk melakukan menilai yang berarti menyimpulkan dan mengolah informasi untuk menentukan pencapaian hasil belajar peserta didik. Guru dalam menilai dilakukan secara terus menerus dan berkesinambungan untuk memantau proses, kemajuan dan perbaikan hasil belajar dalam bentuk ulangan harian, ulangan tengah semester, ulangan akhir semester atau ulangan kenaikan kelas. Menilai digunakan untuk mengetahui pencapaian kompetensi peserta didik, bahan penyusunan laporan hasil belajar dan memperbaiki proses pembelajaran.

\section{Mengevaluasi dengan Peran Pengevaluasi}

Undang-undang Nomor 20 tahun 2003 tentang Sistem Pendidikan Nasional Bab I Pasal 1 ayat 21 menyebutkan bahwa evaluasi pendidikan adalah kegiatan pengendalian, penjaminan, dan penetapan mutu pendidikan terhadap berbagai komponen pendidikan pada setiap jalur, jenjang, dan jenis pendidikan sebagai bentuk pertanggungjawaban penyelenggaraan pendidikan. Stufflebeam \& Shinkfield (1985:159) mengatakan: "Evaluation is process of delineating and providing descriptive and judgmental information about the worth and merit of some object's goals, design, implementation and promote understanding of the involved phenomena" (evaluasi adalah proses penjabaran dan penyediaan informasi deskriptif dan mengarah pada penilaian mengenai nilai dan guna dari tujuan suatu objek, perencanaan, sampai implementasinya dan menghasilkan sebuah pemahaman terhadap fenomena yg ada.) Sehingga kesimpulan dari evaluasi disini adalah penyediaan informasi yang dapat dijadikan bahan pertimbangan pengambilan keputusan.

Uno B. Hamzah (2009:3) mengatakan bahwa guru sebagai evaluator (Evaluator of Student Learning) dengan tujuan utama pe- 
nilaian adalah untuk melihat tingkat keberhasilan, efektivitas, dan efisiensi dalam proses pembelajaran. Selain itu, untuk mengetahui kedudukan peserta dalam kelas atau kelompoknya. Dalam fungsinya sebagai penilai hasil belajar peserta didik, guru hendaknya secara terus-menerus mengikuti hasil belajar yang telah dicapai peserta didik dari waktu ke waktu. Informasi yang telah diperoleh melalui informasi ini akan menjadi umpan balik terhadap proses pembelajaran. Umpan balik akan dijadikan titik tolak untuk memperbaiki dan meningkatkan pembelajaran selanjutnya. Dengan demikian, proses pembelajaran akan terus-menerus ditingkatkan untuk memperoleh hasil yang optimal. Pusat Pengembangan Sistem Pembelajaran UNS (2007:6) menerangkan manfaat dilaksanakannya evaluasi proses dan hasil pembelajaran ada beberapa hal, diantaranya yang penting adalah: (1) Memperoleh pemahaman pelaksanaan dan hasil pembelajaran yang telah berlangsung/ dilaksanakan, (2) Membuat keputusan berkenaan dengan pelaksanaan dan hasil pembelajaran, dan (3) Meningkatkan kualitas proses dan hasil pembelajaran dalam rangka upaya meningkatkan kualitas keluaran.

Dengan demikian guru sebagai pengevaluasi berarti guru melakukan pengukuran suatu kegiatan untuk mengetahui perubahan perilaku yang terjadi pada anak didik. Mengevaluasi dapat juga diartikan suatu keseluruhan kegiatan pengukuran, apakah proses pembelajaran yang dilaksanakan sudah berhasil atau belum. Ukuran keberhasilan adalah peserta didik mengalami perubahan dari belum tahu menjadi tahu, dari belum paham menjadi paham. Langkah-langkah pokok yang harus ditempuh dalam kegiatan evaluasi, yaitu: (1) membuat perencanaan, yang meliputi : menyusun kisi-kisi dan uji coba, (2) mengumpulkan data, (3) mengolah data, (4) menafsirkan data, dan (5) menyusun laporan. Sedangkan prinsip-prinsip evaluasi hasil pembelajaran antara lain: keterpaduan, keterlibatan siswa, koherensi, pedagogis, akuntabilitas.

\section{Kinerja Guru}

Kinerja atau unjuk kerja atau prestasi kerja diartikan sebagai ungkapan kemampuan yang didasari oleh pengetahuan, sikap, keterampilan dan motivasi dalam menghasilkan sesuatu. Bernardin and Russel (1998: 15), mendefinisikan kinerja sebagai berikut, "Per- formance is defined as the record of outcomes produced on a specified job function or activity during a time period" (kinerja cenderung dilihat sebagai hasil dari suatu proses pekerjaan yang pengukurannya dilakukan dalam kurun waktu tertentu). Dari pendapat di atas dapat disimpulkan bahwa kinerja merupakan suatu wujud perilaku seseorang atau organisasi dengan orientasi prestasi. Kinerja seseorang dipengaruhi oleh beberapa faktor seperti: ability, capacity, held, incentive, environment dan validity

Secara lebih komprehensif Brumbrach (Armstrong, 1998: 16) menjelaskan, "Performance means behaviours and results. Behaviours emanate from the performer and transform performance from abstraction to action. Not just the instruments for results, behaviours are also outcomes in their own right - the product of mental and physical effort applied to tasks - and can be judged apart from results", (Kinerja bermakna sikap dan hasil. Sikap berasal dari pekerja dan mengubah kinerja dari abstrak menjadi nyata, Tidak hanya instrumen yang diperlukan, sikap juga menghasilkan sesuatu yang nyata dari hasil usaha mental dan fisik yang diterapkan dalam bentuk latihan-latihan dan dapat dianggap berbeda dari sekedar hasil). Selain menekankan hasil, juga menambahkan perilaku sebagai bagian dari kinerja. Menurut Brumbach, perilaku penting karena akan berpengaruh terhadap hasil kerja seorang pegawai.

Penilaian kinerja seorang guru merupakan bagian penting dari seluruh proses kinerja guru yang bersangkutan. Metode penilaian kinerja dapat dilakukan dengan berbagai pendekatan sesuai dengan aspek yang tersedia seperti sumberdaya, biaya maupun metodologi. Metode penilaian kinerja yang banyak digunakan antara lain metode dari Martinis Yamin \& Maisah (2010: 117-125) beberapa sumber penilaian tenaga kependidikan adalah: penilaian atas diri sendiri, penilaian oleh siswa, penilaian oleh atasan langsung dan penilaian oleh rekan sejawat. Penilaian rekan sejawat pada penilaian tenaga pendidik merupakan penilaian yang dilakukan guru dengan menilai rekan guru yang lain, sehingga penilai dan yang dinilai akan membentuk hubungan dalam sutu proses. Penilaian ini lebih mudah dilakukan tetapi terkendala kebiasaan atau budaya setempat dimana ada rasa 
sungkan/kurang nyaman untuk menilai kurang pada rekan kerja/sejawat ataupun yan lebih tua. Penilaian rekan sejawat akan lebih objektif bila dilakukan dengan angket tertutup.

Permendiknas Nomor 22 tahun 2006 menyebutkan, Pendidikan kejuruan bertujuan untuk meningkatkan kecerdasan, pengetahuan, kepribadian, akhlak mulia, serta keterampilan peserta didik untuk hidup mandiri dan mengikuti pendidikan lebih lanjut sesuai dengan program kejuruannya. SMK adalah lembaga pendidikan formal tingkat menengah atas yang bertujuan untuk mempersiapkan peserta didik bekerja pada bidang tertentu sesuai ketrampilan yang dipelajari sebagai bekal memasuki dunia kerja. Berdasarkan hal tersebut Program Studi Keahlian Teknik Bangunan adalah program studi yang mempersiapkan peserta didik setelah lulus dapat ekerja dan hidup mandiri atau mengikuti pendidikan lebih lanjut dalam bidang teknik bangunan.

Keputusan Dirjen Mandikdasmen Nomor 251/C/Kep/MN/2008 tentang Spektrum Program Keahlian Pendidikan Menengah Kejuruan menjelaskan tentang 6 (enam) bidang Studi keahlian, program studi keahlian dan kompetensi keahlian. Program Studi Keahlian Teknik Bangunan termasuk Bidang Studi Keahlian Teknologi dan Rekayasa yang mempunyai 5 (lima) kompetensi Keahlian yaitu: Teknik Konstruksi Baja, Teknik Konstruksi Kayu, Teknik Konstruksi Batu Dan Beton, Teknik Gambar Bangunan dan Teknik Furnitur. Tujuan Program Studi Keahlian Teknik Bangunan adalah menyiapkan peserta didik untuk: memasuki lapangan kerja serta dapat mengembangkan sikap profesional dalam lingkup keahlian teknik bangunan; mampu memilih karir, berkompetensi dan mengembangkan diri dalam lingkup teknik bangunan; menjadi tenaga kerja tingkat menengah untuk mengisi kebutuhan dunia usaha dan industri pada saat ini maupun masa yang akan datang dalam lingkup keahlian teknik bangunan; serta menjadi warga negara yang produktif, aktif dan kreatif.

Hasil penelitian Imam Muchoyar (2007) menunjukan bahwa 1). Ada perbedaan kinerja antara guru dengan jenjang S-1dibanding guru dengan latar belakang D-III/SM(rerata kinerja guru S-1 97,52331, rerata D-III/SM 97,1429) ini berarti guru dengan jenjang pendidikan S-1 memiliki kinerja yang lebih baik. 2). Terdapat perbedaan kinerja antara guru dengan jumlah pengalaman pelatihan yang pernah diikuti oleh guru. Menurut pendapat siswa guru yang memiliki jumlah pelatihan sebanyak 3 kali adalah yang memiliki kinerja paling tinggi, sedangkan menurut pendapat kepala sekolah guru yang mempunyai pengalaman pelatihan lebih dari 5 kali memiliki kinerja paling tinggi. 3). Sementara itu dari sisi masa kerja guru juga terdapat perbedaan kinerja. Menurut pendapat siswa guru yang mempunyai masa kerja antara 9-12 tahun memiliki kinerja yang paling tinggi (102.00) dan terendah masa kerja diatas 20 tahun (94.1635), sedangkan menurut kepala sekolah kinerja guru yang paling tinggi adalah yang masa kerjanya 5-8 tahun(30.6667) dan terrendah adalah yang masa kerjanya 13-16 tahun(28.1250). Secara umum kecenderungan tingkat kinerja guru menurut siswa aalah sangat tinggi $(8,1 \%)$ tinggi (40\%) kurang tinggi $(44,8 \%)$ dan rendah $(7,1 \%)$ sedangkap pendapat kepala sekolah sangat tinggi $(3,8 \%)$, tinggi $(35,4 \%)$ dan kurang tinggi $(60,8 \%)$.

Hasil penelitian Wagiran (2010) dalam uji hipotesis menunjukan ada pengaruh signifikan kepemimpinan kepala sekolah, budaya sekolah, imbalan, kemampuan guru, komitmen guru, motivasi kerja guru terhadap kinerja guru. Hasil analisis jalur menunjukan bahwa kemampuan guru dan motivasi kerja guru merupakan faktor psikologis yang lebih dominan dalam menentukan kinerja guru secara langsung. Komitmen guru memiliki pengaruh tidak langsung terhadap kinerja guru melalui motivasi kerja guru. Faktor situasional yang lebih dominan dalam menentukan kinerja guru secara langsung adalah kepemimpinan kepala sekolah dan imbalan. Budaya sekolah dan imbalan memiliki pengaruh tidak langsung terhadap kinerja guru melalui kemampuan guru. Dengan demikian upaya peningkatan kinerja guru dapat dilakukan melalui peningkatan kepemimpinan kepala sekolah, budaya sekolah, imbalan, kemampuan guru, komitmen guru dan motivasi kerja guru.

Dengan demikian maka perlu untuk mengetahui kinerja guru sebagai pendidik, pengajar, pembimbing, pengarah, pelatih, penilai dan pengevaluasi serta kinerja guru secara keseluruhan sesuai dengan tugas pokok dan fungsi guru pada program keahlian teknik 
bangunan di daerah Istimewa Yogyakarta tahun2013.

\section{METODE PENELITIAN}

Penelitian ini merupakan penelitian deskriptif kuantitatif. Penelitian dilaksanakan pada SMKN yang ada di propinsi Daerah Istimewa Yogyakarta yang memiliki program Keahlian Teknik Bangunan. Penelitian dibagi menjadi 3 tahap penelitian yaitu tahap pra survei yang telah dilaksanakan bulan Juli 2012, uji coba instrumen bulan Februari 2013 dan pelaksanaan penelitian bulan Maret-April 2013. Penelitia ini adalah penelitian populasi dimana seluruh guru produktif SMKN Program Keahlian Teknik Bangunan di Daerah Istimewa Yogyakarta dijadikan sampel penelitian dengan total 115 orang guru yang terdiri dari 8 SMKN yaitu: SMKN 2 Yogyakarta, SMKN 3 Yogyakarta, SMKN 2 Depok, SMKN 1 Seyegan, SMKN 2 Pengasih, SMKN 1 Sedayu, SMKN 1 Pajangan, SMKN 2 Wonosari.

Variabel dalam penelitian ini adalah kinerja guru dengan subvariabel: pendidik, pengajar, pembimbing, pengarah, pelatih, penilai, pengevaluasi. Teknik pengumpulan data pada penelitian ini menggunakan angket tertutup yaitu seperangkat daftar pernyataan untuk mengungkap/mengetahui kinerja guru. Angket diberikan kepada guru untuk diisi berdasarkan pendapat para guru tentang rekan kerja dalam satu tim mengajar. Instrumen yang digunakan disusun berdasarkan pada definisi operasional dari subvariabel penelitian.

Penelitian ini dilakukan untuk mengetahui tingkat kinerja guru SMK Program Keahlian Teknik Bangunan di DIY tahun 2013berdasarkan tugas pokok dan fungsi guru. Teknik analisis data yang digunakan adalah analisis statistik deskriptif kuantitatif. Sugiyono (2011:207) mengatakan bahwa statistik deskriptif adalah statistik yang digunakan untuk menganalisa data dengan cara deskriptif atau menggambarkan data yang telah terkumpul sebagaimana adanya tanpa bermaksud membuat kesimpulan yang berlaku untuk umum atau generalisasi. Analisis deskriptif digunakan untuk menggambarkan atau menganalisa data hasil penelitian yaitu dengan mengungkap skor rerata median (Me), Mode (Mo), simpangan baku, nilai minimum dan maksimum, kurtosis dan analisis lainnya dari tiap-tiap variabel. Penelitian kuantitatif adalah pengumpulan data-datanya adalah data-data kuantitatif atau berupa angka

\section{HASIL PENELITIAN DAN PEMBAHASAN}

Kegiatan penelitian dilakukan di Daerah Istimewa Yogyakarta dengan jumlah responden 115 guru program keahlian Teknik Bangunan yang diperoleh dari 8 (delapan) SMKN di Daerah Istimewa Yogyakarta. Deskripsi data penelitian merupakan penyajian hasil penelitian di lapangan, guna memberikan gambaran umum mengenai penyebaran data yang diperoleh. Data yang disajikan masih berupa data mentah yang diolah menggunakan teknik deskripsi statistik menggunakan bantuan komputer seri program SPSS for Windows versi 16 sehingga diperoleh rerata/mean $(\mathrm{M})$, standar deviasi (SD), modus (Mo), median (Me), skor maksimum dan skor minimum disertai histogram untuk setiap variabel penelitian. Deskripsi data disajikan pada Tabel 1.

Tabel 1. Rangkuman Statistik Deskriptif

\begin{tabular}{|c|c|c|c|c|c|c|c|}
\hline & Pendidik & Pengajar & Pembimbing & Pengarah & Pelatih & Penilai & Pengevaluasi \\
\hline Valid & 115 & 115 & 115 & 115 & 115 & 115 & 115 \\
\hline Mean & 92,10 & 139,13 & 117,69 & 74,19 & 85,97 & 50,29 & 33,46 \\
\hline Median & 92,00 & 137,00 & 115,00 & 74,00 & 85,00 & 50,00 & 33,00 \\
\hline Mode & 87 & 148 & 115 & 74 & 78 & 45 & 30 \\
\hline Std. Deviation & 9,475 & 16,480 & 12,474 & 8,358 & 9,827 & 5,913 & 4,366 \\
\hline Minimum & 59 & 106 & 85 & 55 & 65 & 37 & 15 \\
\hline Maximum & 116 & 172 & 144 & 92 & 110 & 60 & 40 \\
\hline
\end{tabular}


Kinerja guru berdasarkan tugas pokok dan fungsi guru ini dimintakan pendapat dari rekan guru satu tim dalam mengajar teknik produktif. Data kuantitatif yang diperoleh dari tujuh subvariabel akan diolah dengan cara membandingkan persentase perolehan skor setiap responden pada tiap kasus dengan kriteria penilaian. Adapun penyajian tabel perhitungan data dengan mencari prosentase berdasarkan kriteria sangat baik, baik, cukup baik dan kurang baik sebagai berikut:

Tabel 2. Rangkuman Hasil Penelitian

\begin{tabular}{lcccc}
\hline Subvariabel & \multicolumn{4}{c}{ Persentase Kategori } \\
\cline { 2 - 5 } & $\begin{array}{l}\text { Sangat } \\
\text { Tinggi }\end{array}$ & Tinggi & $\begin{array}{c}\text { Cukup } \\
\text { Tinggi }\end{array}$ & $\begin{array}{c}\text { Kurang } \\
\text { Tinggi }\end{array}$ \\
\hline Pendidik & 14,78 & 40,00 & 35,65 & 9,57 \\
Pengajar & 13,04 & 32,17 & 36,52 & 18,26 \\
Pembimbing & 19,13 & 22,61 & 44,35 & 13,91 \\
Pengarah & 16,52 & 38,26 & 31,30 & 13,91 \\
Pelatih & 18,26 & 31,30 & 41,74 & 8,70 \\
Penilai & 22,61 & 33,91 & 35,65 & 7,83 \\
Pengevaluasi & 20,87 & 35,65 & 37,39 & 6,09 \\
\hline
\end{tabular}

Kemampuan guru program keahlian teknik bangunan sebagai pendidik dalam penelitian ini $40 \%$ berkategori tinggi antara lain disebabkan. (1) Guru mampu membuat peserta didik merasa nyaman dan diterima di kelas dan memperhatikan potensi yang dimiliki peserta didik. (2). Pengalaman mengajar yang lama, hal ini bisa dilihat dari usia sebagian besar guru yng mengajar pada program keahlian teknik bangunan berada pada usia 50-60 tahun. (3) Guru mampu berinteraksi dan berkomunikasi dengan teknik dan metode yang sesuai untuk membangun kepercayaan diri dan mendidik untuk percaya pada diri mereka sendiri (4). Guru yang mengajar sudah lulus sertifikasi dan mendapat tunjangan sertifikasi sehingga menambah motivasi untuk melaksanakan tugas sebagai pendidik. (5). Kemampuan guru yang baik dalam memahami perkembangan peserta didik bahwa tidak semua peserta didik belajar dengan cara yang sama dan tingkatan yang sama dan memberikan pujian serta motivasi untuk menjadi lebih baik, (6) Pembinaan dan dukungan kepala sekolah terhadap edukasi guru yang berkelanjutan.
Hal senada juga disampaikan oleh Davis dan Thomas (1989:147) mengemukakan

"Some research-based correlates of teacher effectiveness in the area of classroom climate include the following: a) having strong interpersonal skills, particularly empathy atau, respect, and genuineness. b). Having good relationships with students. c). Genuinely accepting and caring about students. d). Expressing interest and enthusiasm. e). Creating an atmosphere of cooperation and group cosiveness. f). Involving students in organizing and planning. g). Listening to students and respecting their right to speak during recitations and discussions. h). Minimising friction of any sort"

(Kemampuan yang terkait dengan iklim kelas: a) memiliki kemampuan interpersonal, khususnya kemampuan untuk menunjukkan empati, penghargaan kepada peserta didik dan ketulusan, b) memiliki hubungan baik dengan peserta didik, c) secara tulus menerima dan memperhatikan peserta didik, d) menunjukkan minat dan anthusias yang tinggi dalam mengajar, e) mampu menciptakan atmosfer untuk bekerja sama dan kohesivitas dalam kelompok, f) melibatkan peserta didik dalam mengorganisasikan dan merencanakan kegiatan pembelajaran, g) mampu mendengarkan peserta didik dan menghargai hak peserta didik untuk berbicara dalam setiap diskusi, h) meminimalkan friksi-friksi di kelas jika ada). Pendidik yang efektif mampu berempati dan berusaha memahami perkembangan peserta didik, bersikap tulus dan mengungkapkan keiklasan sikap dan tutur kata dalam pergaulan di lingkungan sekolah.

Hasil analisis yang diperoleh dari pendapat para guru program keahlian teknik bangunan tentang rekan kerja satu tim terdapat 42 orang guru atau $36,52 \%$ yang menilai rekan kerjanya memiliki kinerja dan kemampuan sebagai sebagai pengajar yang cukup tinggi. Kemampuan guru program keahlian teknik bangunan sebagai pengajar dalam penelitian ini berkriteria cukup tinggi antara lain disebabkan. (1). Kemampuan guru yang cukup dalam pendekatan pembelajaran dari berbagai media, dan sumber belajar serta memberi ruang untuk berhubungan antar peserta didik, guru, lingkungan dan sumber 
belajar lain (2). Kemampuan guru yang cukup untuk memahami dan melaksanakan pengajaran dengan berbagai metode dan teknik pengajaran (3). memberi kesempatan berpikir, menganalisis, menyelesaikan masalah yang dihadapi peserta didik dan bertindak tanpa rasa takut (4).Kemampuan guru yang cukup dalam membantu menyelesaikan masalah dan memfasilitasi penyelesaian masalah yang dialami peserta didik dalam menuntaskan kompetensi, mengecek hasil eksplorasi dengan memberi arahan agar peserta didik melakukan kontrol terhadap hasil kegiatan yang telah dilakukan. (5). Kemampuan guru yang cukup sebagai narasumber dan fasilitator dalam menjawab pertanyaan peserta didik yang menghadapi kesulitan, pembelajaran yang kooperatif dan kolaboratif. (6). Kemampuan guru yang cukup dalam menggunakan teknologi pembelajaran dan menerapkannya dalam pembelajaran sehari-hari, (7). Pembinaan kepala sekolah maupun dari dinas terkait yang cukup membantu dalam pemahaman silabus dan kemampuan membuat RPP sehingga dapat dilaksanakan dalam proses pembelajaran.

Kemampuan guru sebagai pengajar ini sesuai dengan pendapat Wong \& Wong (2009:9) mengatakan "the three characteristics of an effective teacher (a) positive expectations, (b) classroom manajement, (c) lesson mastery" bahwa tiga ciri pengajar efektif yaitu: (a) memiliki expektasi positif (memiliki harapan yang tinggi) terhadap kesuksesan peserta didik, (b) Manajer kelas yang andal, (c) Mengetahui cara merancang pelajaran untuk dapat dikuasai peserta didik. Seperti yang telah dipahami di kajian teori bahwa kemampuan guru sebagai pengajar adalah kemampuan untuk memudahkan peserta didi memahami ilmu dan pengetahuan yang diberikan. Harapan yang yang dibangun agar peserta didik mampu dengan mudah memahami pengetahuan yang diajarkan merupakan salah satu motivasi untuk keberhasilan pengajaran disamping kemampuan guru mengatur dan menguasai kelas. Guru sebagai pengajar yang baik akan mampu merancang pembelajaran sesuai dengan metode dan gaya belajar peserta didik.

Hasil yang diperoleh dari pendapat para guru terdapat 51 orang guru atau $44,35 \%$ yang menilai rekan kerjanya memiliki kinerja dan kemampuan sebagai sebagai pembimbing yang cukup tinggi. Kemampuan guru program keahlian teknik bangunan sebagai pembimbing dalam penelitian ini berkriteria cukup baik antara lain disebabkan. (1) pengalaman mengajar yang lama, hal ini bisa dilihat dari usia sebagian besar guru yang mengajar pada program keahlian teknik bangunan berada pada usia 50-60 tahun. (2) adanya pembinaan dari kepala sekolah maupun dari dinas terkait tentang pembimbingan peserta didik usia remaja (3) kemampuan guru yang cukup dalam memahami gaya belajar dan kemampuan peserta didik (4) kemampuan guru dalam menghargai orang lain secara positif tanpa syarat, ramah, bersahabat pada semua warga yang ada di lingkungan sekolah, bersikap jujur dalam pergaulan dengan warga sekolah (5) mendorong peserta didik untuk selalu meningkatkan kompetensi yang dimiliki, komunikatif dan mudah dimengerti oleh orang lain, bersikap tepat, jelas, cermat, dan dapat dipahami peserta didik (6) guru berkemampuan mengembangkan potensi peserta didik melalui metode mengajar yang bernuansa bimbingan yang religius, psikologis, sosiologis, budaya, dalam berinteraksi di lingkungan sekolah serta memberikan kesempatan untuk berdiskusi dengan peserta didik dan sesama guru.

Hal ini senada dengan pendapat Sofyan S. Willis (2003:25) mengatakan bahwa guru sebagai pembimbing berperilaku membimbing. Perilaku membimbing adalah perilaku yang memancar dari aspek-aspek kepribadian sebagaimana ditampilkan oleh seorang pembimbing dengan karakteristik-karakteristik sebagai berikut: a) empati, dapat merasakan apa yang dirasakan murid; b) attending, ramah, bersahabat, terbuka; c) supporting-motivating, mendorong, memotivasi; d) Unconditional positive regard, menghargai secara positif tanpa syarat, menerima, toleran (memaafkan apapun keadaannya); e) Genuine, asli, jujur; f) Respect, menghormati diri dan hakhaknya; g) Correct, tepat, jelas, cermat, mudah dimengert; h) Realistik; menerima kenyataan; i) Cerdas, kreatif, dan menguasai ilmu; j) berwawasan religius, psikologis, sosiologis, dan budaya; k) terampil dalam tugas. Dengan demikian maka dapat disimpulkan bahwa kemampuan guru SMK program keahlian teknik bangunan di DIY dalam pembelajaran telah menerapkan metode mengajar yang 
bernuansa bimbingan dalam hubungan antara guru dan peserta didik

Pendapat para guru program keahlian teknik bangunan tentang rekan kerja satu tim diperoleh hasil 44 orang guru atau 38,26\% yang menilai rekan kerjanya memiliki kinerja dan kemampuan sebagai sebagai pengarah yang tinggi. Nilai 44 orang guru ini diperoleh dari jumlah skor antara $101,575 \geq X \geq 74,19$, dimana 74,19 adalah rerata skor pengarah. Dengan demikian maka kemampuan guru SMK program keahlian teknik bangunan sebagai pengarah $38,26 \%$ berada pada posisi diatas rata-rata. Kemampuan guru program keahlian teknik bangunan sebagai pengarah dalam penelitian ini berkriteria baik antara lain disebabkan: (1) kemampuan guru yang baik dalam hal membangun harapan bahwa peserta didik mampu berprestasi; (2) kemampuan guru yang baik dalam menjelaskan tujuan pembelajaran yang diharapkan dan mendorong mencapai hasil yang telah ditargetkan; (3) kemampuan guru yang baik dalam membantu peserta didik memahami permasalahan yang dihadapi dan cara penyelesaiannya; (4) memberikan pengarahan pada peserta didik agar belajar sesuai dengan kemampuan pribadinya

Hal ini sesuai dengan beberapa kriteria yang ada pada The Teacher As An Organizer (http://www2.honolulu.hawaii.edu), dimana guru sebagai pengarah beranggapan lebih baik membangun kekuatan daripada menekankan kelemahan. Guru harus terus berasumsi bahwa setiap peserta didik mampu berprestasi, berkontribusi, walaupun dengan prestasi yg sangat rendah dan bahkan sangat jauh dari yg diharapkan. Kemampuan guru sebagai pengarah untuk menggerakan peserta didik mencapai hasil yang telah ditargetkan akan berfungsi efektif dengan mengklarifikasi tujuan dan mencapai hasil yg diharapkan. Pengarah dalam ranah pendidikan berusaha untuk mendorong dan menghargai inisiatif. Tetapi bukan hanya sekedar inisiatif yang setengah-setengah. Inisiatif yg diharapkan adalah inisiatif yg selalu terkonsep dgn baik sesuai tujuan kurikulum. Guru sebagai penarah mampu memelihara karena tanpa kontrol dan usaha yang terus menerus dikembangkan di kelas hanya akan mencapai tujuan yg biasa-biasa saja

Pendapat para guru program keahlian teknik bangunan tentang rekan kerja satu tim diperoleh hasil 48 orang guru atau 41,70\% yang menilai rekan kerjanya memiliki kinerja dan kemampuan sebagai sebagai pelatih yang cukup tinggi.

Kemampuan guru program keahlian teknik bangunan sebagai pelatih dalam penelitian ini berkriteria cukup baik baik antara lain disebabkan: (1) pengalaman mengajar yang cukup lama, hal ini bisa dilihat dari usia sebagian besar guru yng mengajar pada program keahlian teknik bangunan berada pada usia 50-60 tahun; (2) guru mempunyai cukup kompetensi yang terlatih dalam mengajarkan kompetensi dilihat dari ijasah terakhir yang sebagian besar adalah lulusan S-1 pendidikan teknik bangunan; (3) guru yang mengajar sudah lulus sertifikasi dan mendapat tunjangan sertifikasi sehingga menambah motivasi untuk melaksanakan tugas sebagai pendidik; (4) pengalaman pelatihan yang cukup menambah kemampuan guru menguasai ketrampilan melatih dengan karakter; (5) guru mampu kolaborasi dengan peserta didik menggunakan berbagai sumber belajar; (6) program MGMP yang menjadi wadah bagi guru untuk bisa berbagi ilmu dan pengalaman sesama guru program keahlian teknik bangunan dalam meningkatkan kemampuan sebagai pelatih; (7). Guru mempunyai skala prioritas dalam melaksanakan pembelajaran ketrampilan

Hal ini senada dengan pendapat Endang Rini Sukamti (http://staff.uny.ac.id) bahwa kemampuan profesional sebagai guru, baru kemudian menjadi pelatih. Pernyataan ini mengandung pengertian bahwa proses mangajar adalah sangat penting, baik formal (di dalam) ataupun dalam aktivitas olahraga, dan ini tidak berarti bahwa pelatihan lebih kurang penting dibandingkan dengan pengajaran di sekolah ataupun sebaliknya. Guru mengetahui cara melatihnya. Dalam kaitan ini pengalaman sebagai pemain dapat dipergunakan dalam melatih, meskipun tidak selalu dibutuhkan untuk mencapai keberhasilan pelatihan. Pelatih yang baik juga mempunyai kualitas pribadi yang menarik, sehingga atlit yang dilatih atau dalam bimbingannya menjadi loyal serta berusaha untuk melakukan perintahnya, dengan tidak merasa terpaksa. Salah satu kualitas dasar yang harus dipenuhi adalah masalah karakter. Hal ini sangat penting bagi profesi pelatihan, sebab karakter ini dapat menunjukkan siapa kita?, bagaimana kita?, dan apa yang orang fikirkan tentang kita? Selain itu pelatih berada dalam posisi yang 
mempunyai pengaruh cukup kuat untuk menanamkan kehidupan yang baik kepada orang lain. Oleh karena itu karakter ini merupakan salah satu tes untuk sesuai tidaknya seseorang memangku jabatan dalam profesi pelatihan.

Kinerja guru sebagai penilai dapat dilihat hasil analisis yang diperoleh dari pendapat para guru program keahlian teknik bangunan tentang rekan kerja satu tim. Hasil yang diperoleh terdapat 41 orang guru atau $35,65 \%$ yang menilai rekan kerjanya memiliki kinerja dan kemampuan sebagai sebagai penilai yang cukup tinggi.

Kemampuan guru program keahlian teknik bangunan sebagai penilai dalam penelitian ini berkategori tinggi antara lain disebabkan: (1) kemampuan guru yang cukup dalam menggunakan silabus yang memuat rancangan penilaian; (2) Kemampuan guru yang cukup dalam mendeskripsi kompetensi yang telah dikuasai peserta didik; (3) Guru cukup mampu mengembangkan instrumen dan mengembangkan pedoman penilaian sesuai dengan bentuk dan teknik penilaian yang dipilih; (4) adanya pembinaan dari kepala sekolah maupun dari dinas terkait tentang tahapan penilaian; (5) adanya MGMP guru teknik bangunan yang menjadi wadah bagi guru untuk bisa berbagi ilmu dan pengalaman; (6) kemampuan guru yang cukup dalam melaksanakan tes, pengamatan, penugasan, dan/atau bentuk lain yang diperlukan dalam penilaian.

Hasil penelitian ini senada dengan pendapat Akhmad Sudrajat (2008: http:// akhmadsudrajat.wordpress.com) yang menjelaskan bahwa penilaian (assessment) adalah penerapan berbagai cara dan penggunaan beragam alat penilaian untuk memperoleh informasi tentang sejauh mana hasil belajar peserta didik atau ketercapaian kompetensi (rangkaian kemampuan) peserta didik. Penilaian menjawab pertanyaan tentang sebaik apa hasil atau prestasi belajar seorang peserta didik. Hasil penilaian dapat berupa nilai kualitatif (pernyataan naratif dalam kata-kata) dan nilai kuantitatif (berupa angka). Pengukuran berhubungan dengan proses pencarian atau penentuan nilai kuantitatif tersebut. Pengukuran (measurement) adalah proses pemberian angka atau usaha memperoleh deskripsi numerik dari suatu tingkatan di mana seorang peserta didik telah mencapai karakteristik tertentu. Tes adalah cara penilaian yang dirancang dan dilaksanakan kepada peserta didik pada waktu dan tempat tertentu serta dalam kondisi yang memenuhi syarat-syarat tertentu yang jelas. Menilai hasil pembelajaran merupakan serangkaian kegiatan untuk memperoleh, menganalisis, dan menafsirkan data tentang proses dan hasil belajar peserta didik yang dilakukan secara sistematis dan berkesinambungan. Melalui penilaian hasil pembelajaran diperoleh informasi yang bermakna untuk meningkatkan proses pembelajaran berikutnya serta pengambilan keputusan lainnya. Menilai hasil pembelajaran dilaksanakan secara terintegrasi dengan tatap muka seperti ulangan harian dan kegiatan menilai hasil belajar dalam waktu tertentu seperti ujian tengah semester dan akhir semester.

Hasil yang diperoleh tentang kinerja guru sebagai pengevaluasi terdapat 43orang guru atau $37,39 \%$ yang menilai rekan kerjanya memiliki sebagai pengevaluasi yang cukup tinggi. Kemampuan guru program keahlian teknik bangunan sebagai pengevaluasi dalam penelitian ini berkategori cukup tinggi antara lain disebabkan; 1) guru cukup mampu melaksanakan evaluasi pada kompetensi yang sesuai dengan yang diajarkan; 2) guru mampu mempertanggungjawabkan hasil penilaian dari segi teknik, proses maupun hasil; 3) kemampuan guru yang cukup dalam menginformasikan kemajuan belajar peserta didik hasil evaluasi; 4) kemampuan guru dalam merencanaan evaluasi yang dapat disesuaikan secara harmonis dengan tujuan instruksional

Hasil penelitian ini sejalan dengan penelitian Pusat Pengembangan Sistem Pembelajaran UNS (2007:6) yang menerangkan manfaat dilaksanakannya evaluasi proses dan hasil pembelajaran ada beberapa hal, diantaranya yang penting adalah: (1) memperoleh pemahaman pelaksanaan dan hasil pembelajaran yang telah berlangsung/dilaksanakan; (2) membuat keputusan berkenaan dengan pelaksanaan dan hasil pembelajaran, dan; (3) meningkatkan kualitas proses dan hasil pembelajaran dalam rangka upaya meningkatkan kualitas keluaran. Dalam praktek pembelajaran secara umum pelaksanaan evaluasi program pembelajaran menekankan pada evaluasi proses pembelajaran (evaluasi manajerial) dan evaluasi hasil belajar (evaluasi subtansial). Hal ini didasarkan pada pemikiran bahwa 
pelaksanaan pembelajaran kedua jenis evaluasi tersebut merupakan komponen sistem pendidikan yang sangat penting. Evaluasi kedua jenis komponen yang dapat dipergunakan untuk mengetahui kekuatan dan kelemahan pelaksanaan dan hasil pembelajaran. Selanjutnya masukan tersebut pada gilirannya dipergunakan sebagai bahan dan dasar perbaikan kualitas proses pembelajaran menuju ke perbaikan kualitas hasil pembelajaran.

Kinerja guru program keahlian teknik bangunan secara keseluruhan dalam penelitian ini berkriteria cukup baik.

Kinerja guru program keahlian teknik bangunan dalam penelitian ini jika dikaitkan dengan latar belakang pendidikan memperlihatkan bahwa: jumlah guru dengan latar belakang D3 sebanyak 8 (delapan) guru atau $6,96 \%$, S1 sebanyak 96 (sembilan puluh enam) guru atau $83,47 \%$ dan S2 sebanyak 11(sebelas) guru atau 9,57\%. Sataus guru yang telah bersertifikasi sebanyak 101 (seratus satu) guru atau $87,83 \%$ dan yang belum sebanyak 14 (empat belas) guru atau 12,17\% . Dengan demikian maka sebagian besar guru telah memenuhi syarat kualifikasi pendidikan minimal dan guru yang layak desebut sebagai guru yang telah sesuai dengan profesinya. Akan tetapi bila dilihat dari kinerja guru secara keseluruhan menunjukan bahwa kinerja guru berkriteria cukup tinggi. Kinerja guru yang tinggi hanya pada kemampuan guru sebagai pendidik sebanyak $40 \%$ dan pengarah $38,26 \%$, selebihnya kemampuan guru sebagai pengajar, pembimbing, pelatih, penilai dan pengevaluasi berkriteria cukup tinggi, pencapaian kinerja tinggi apalagi kriteria sangat tinggi masih sangat perlu peningkatan. Hal ini memberikan informasi bahwa kinerja guru belum sesuai dengan harapan meskipun tingkat pendidikan yang baik dan status guru telah bersertifikasi. Simanjuntak dalam artikel Ria Guntur (http://www.fajar.co.id) mengatakan tingkat kemampuan intelegensi seseorang dapat dilihat dari jenjang pendidikan yang telah dilaluinya. Dari pendapat tersebut memperlihatkan bahwa semakin tinggi tingkat pendidikan guru akan semakin tinggi pula tingkat intelegensinya, dengan tingkat intelegensi yang tinggi maka guru akan mampu memberikan masukan terhadap kinerja guru yang semakin tinggi juga. Peningkatan kinerja guru menjadi lebih tinggi harus selalu diikuti den- gan pembinaan dan pelatihan sesuai bidang keahlian yang diperlukan guru.

Imam Muchoyar (2007:124) menyimpulkan "Tingkat kinerja guru SMK Negeri bidang keahlian teknik bangunan di DIY menurut pendapat peserta didik sangat tinggi $8,1 \%$, tinggi $40 \%$ kurang tinggi $44,8 \%$ dan rendah $7,1 \%$. Pendapat kepala sekolah sangat tinggi $3,8 \%$ tinggi $35,4 \%$, kurang tinggi $60,8 \%$ dan rendah $0 \%$, sehingga dapat disimpulkan bahwa kinerja guru cenderung kurang tinggi". Hasil yang diperoleh dalam penelitian tersebut tidak berbeda jauh dengan penelitian ini dimana terdapat kesamaan bahwa kinerja guru SMK kurang tinggi.

Peningkatan kinerja guru dapat dilakukan dengan meningkatkan kemampuan dan keterampilan yang sesuai dengan materi pembelajaran yang dikuasai dan motivasi guru dalam melaksanakan tugasnya. Peningkatan kompetensi bisa dilakukan dengan mengikuti pendidikan dan pelatihan, workshop, temu ilmiah, penelitian tindakan kelas dan sebagainya. Peningkatan motivasi bagi guru, dapat dilakukan Tinggi motivasi dari dalam diri sendiri maupun motivasi dari luar diri.

\section{SIMPULAN DAN SARAN}

\section{Simpulan}

Kinerja guru SMK program keahlian teknik bangunan di DIY tahun 2013 sebagai pendidik berkategori baik, sebagai pengajar dalam kategori cukup baik 36,52\%, sebagai pembimbing berkategori cukup baik, sebagai pengarah berkategori baik, sebagai pelatih berkategori cukup baik, sebagai penilai berkategori cukup baik, sebagai pengevaluasi berkategori cukup baik dan kinerja guru SMK program keahlian teknik bangunan di DIY secara keseluruhan rata-rata berkategori cukup baik.

\section{Saran}

Bagi sekolah, untuk meningkatkan kinerja guru SMK perlu memprogramkan pengadaan pelatihan penelitian tindakan kelas agar guru mampu mengevaluasi dan menerapkan metode belajar yang digunakan, dan juga pelatihan ketrampilan mengajar praktik di bengkel maupun laboratorium dengan mengimplementasikan dan mengevaluasi pembelajaran yang telah dilakukan. 
Bagi guru perlu ada monitoring kinerja guru intern secara periodik dalam kelompok keahlian dan hasilnya dapat digunakan untuk memperbaiki dan mengarahkan menjadi kinerja yang lebih baik. Perlu peningkatan kinerja secara terus menerus dengan meningkatkan pengetahuan dan ketrampilan sesuai dengan tugas pokok dan fungsi guru yang disesuaikan dengan perkembangan teknologi, penguasaan teknologi informasi, pengembangan media belajar dan sebagainya. Kesadaran untuk meningkatkan kinerja guru dapat dilakukan melalui pendidikan dan pelatihan, motivation training, seminar, lokakarya, lomba, penelitian dan lain-lain.

Bagi Dinas Pendidikan perlu diadakan kegiatan yang dapat meningkatkan kemampuan dan ketrampilan dalam menjalankan tugas pokok dan fungsi guru seperti penyelenggaraan pendidikan dan pelatihan, pemberian penghargaan bagi guru yang berprestasi, beasiswa untuk melanjutkan pendidikan yang lebih tinggi dan sebagainya

Bagi peneliti selanjutnya yang berkeinginan meneliti kinerja guru yang sesuai dengan tugas pokok dan fungsi guru dapat menjadikan penelitian ini sebagai referensi untuk mengembangkan masalah dan responden yang lebih luas, serta mengembangkan penelitian pada penilaian atasan, pengguna (peserta didik) ataupun instansi yang berhubungan dengan pendidikan (dunia usaha/industri dan rekanan pendidikan).

\section{DAFTAR PUSTAKA}

Ahmad Juntika Nurihsan. (2006). Bimbingan dan konseling dalam berbagai latar kehidupan. Bandung: Refika Aditama, 7

Akhmad Sudrajat. (2008). Penilaian hasil belajar siswa, diposted 1 Mei 2008 pada http://akhmadsudrajat.wordpress.com/2 008/05/01/penilaian-hasil-belajar/, $\mathrm{di}$ ambil tanggal 13 September 2012

Armstrong, M. \& Baron, A. (1998). Performance management. London: Institute of Personal and Development, 16

Anik Sulistyawati. (2009). Kemampuan guru gunakan ICT masih rendah. diambil dari http://www.harianjogja.com/baca/ 2009/09/09/kemampuan-guru-gunakanict-masih-rendah-4479 tanggal 14 September 2012
Bernardin, H. Jonh \& Russell, E. A., (1998). Human Resource Management Second Edition. Singapore: McGraw-Hill. H. 15

Davis, Gary A \& Thomas, Margareth A. (1989). Effective schools and effective teachers. 160 Gould Street Needham Heights, Massachusetts, A Division of Simon \& Schuster: Allyn and Bacon, 147

Depdiknas. (1990). Peraturan Pemerintah nomor. 29 tahun 1990 tentang pendidikan menengah

Depdiknas. (2003). Undang-undang nomor 20 tahun 2003 tentang sistem pendidikan nasional.

Depdiknas. (2005). Peraturan Pemerintah nomor 19 tahun 2005 tentang standar nasional pendidikan.

Depdiknas. (2006). Peraturan Menteri Pendidikan Nasional nomor 22 tahun 2006 tentang standar isi untuk satuan pendidikan dasar dan menengah.

Depdiknas. (2007). Peraturan Menteri Pendidikan Nasional nomor 20 tahun 2007 tentang standart penilaian pendidikan

Depdiknas. (2007). Peraturan Menteri Pendidikan Nasional nomor 41 tahun 2007 tentang standar proses untuk satuan pendidikan dasar dan menengah

Depdiknas. (2008) Keputusan Dirjen Mandikdasmen nomor 251/c/kep/mn/ 2008 tentang spektrum program keahlian pendidikan menengah kejuruan

Depdiknas. (2008). Pedoman penghitungan beban kerja guru departemen pendidikan nasional. direktorat jenderal peningkatan mutu pendidik dan tenaga kependidikan tahun 2008

E. Mulyasa. (2006). Menjadi guru profesional. Bandung: PT Rosdakarya, 37

Endang Rini Sukamti. (2009). Profesional pelatih cabang olahraga yang berkarakter untuk mencapai prestasi maksimal. diambil tanggal 21 November 2012 dari: http://staff.uny.ac.id/sites/default/ files/131568302/PROFESIONAL\%20P ELATIH\%20CABANG\%20OLAHRA GA\%20YANG\%20BERKARAKTER \%20UNTUK\%20MENCAPAI\%20PRE STASI\%20MAKSIMAL.pdf,

Gagne, Robert M., Leslie J., Briggs, and Walter W. Wagner. (1992). Principles 
of intructional design. Orlando: Holt, Harcourt Brace \& Company, h.3

Georgia Department of Education. (2012). Teacher assessment on performance standards reference sheet performance standards and sample performance indicators state school superintendent. Dr. John D. Barge, State School Superintendent, July 16, 2012, Georgia Department of Education

Gurney, Philip. (2007). Five factors for effective teaching, New Zealand Journal of Teachers' Work, Volume 4, Issue 2, 8998, diambil dari http://www.teachers work.ac.nz/journal/volume4_issue2/ gurney.pdf tanggal 12 Agustus 2012

Imam Muchoyar.( 2007). Kinerja guru smk bidang keahlian teknik bangunan di daerah istimewa yogyakarta. Tesis magister, tidak diterbitkan, Universitas Yogyakarta, Yogyakarta :124

Jamaluddin Noor Popoy. (1978). Ilmu pendidikan, Bagian Proyek Peningkatan Mutu PGAN. DEPAG, hal 1

Maklassa, Dg. (2012). Kualitas pendidikan rendah karena kinerja guru. Diambil tanggal 20 Jul 2012 dari http://www.igi. or.id/waca.php?subaction=showfull\&id $=1342755224 \&$ archive $=\&$ start_from $=$ \&ucat $=1 \&$

Maritje Terok. (2010). Mutu pendidikan teknologi dan kejuruan melalui profesionalisme guru dan dosen. Makalah Internasional disajikan dalam Seminar Peran LPTK Dalam Pengembangan Pendidikan Vokasi di Indonesia Jurusan PKK ISSN 1907-2066 Fakultas Teknik Universitas Negeri Manado,424

Martinis Yamin \& Maisah. (2010). Standarisasi kinerja guru. Jakarta: GP Press: 117-125

Muhammad Furqon Hidayatulloh. (2009). Guru sejati: membangun insan berkarakter kuat dan cerdas. Surakarta: Yuma Pustaka, 144

Nanang Hanafiah, \& Cucu Suhana. (2009). Konsep strategi pembelajaran. Bandung: Refika Aditama, 75

Popham, W.J. (1995). Classroom assessments: what teachers need to know. Toronto:Allyn Bacon, 3

Roestiyah NK. (1982). Masalah-masalah ilmu keguruan. Jakarta: Bina Aksara, 86
Simamora, Roymond, (2009) Buku ajar pendidikan dalam keperawatan, Jakarta, EGC

Sofyan S. Willis. (2003). Peran guru sebagai pembimbing (suatu studi kualitatif). Jurnal Mimbar Pendidikan No. 1/XXII/ 2003, Universitas Pendidikan Indonesia, halaman 25-32 diambil dari http:// file.upi.edu/Direktori/JURNAL/JURN AL MIMBAR PENDIDIKAN/MIMB AR_NO_1_2003/Peran_Guru_Sebagai _Pembimbing_\%28Suatu_Studi_Kualit atif\%29.pdf pada tanggal 12 Desember 2012

Stufflebeam, D.L \& Shinkfield,A.J. (1985). System evaluation. Boston: Kluwer Nijhof Plubishing, 159

Sugiyono. (2011). Metode penelitian pendidikan. Bandung: Alfabeta, 207

Suryosubrata. (1983). Beberapa aspek dasar kependidikan: Jakarta:Bina Aksara, 26

The Teacher As An Organizer. diambil tanggal 01 oktober 2012 http://www2.hono lulu.hawaii.edu/facdev/guidebk/teachtip Im-files/m-organi.htm.

Tim PEKERTI-AA PPSP. (2007). Evaluasi pembelajaran. Surakarta: LPP Universitas Sebelas Maret, 6

Uno, B. Hamzah. (2009). Mengelola kecerdasan dalam pembelajaran. Jakarta: PT. Bumi Aksara

Wagiran. (2010). Determinan kinerja guru smk kelompok keahlian teknologi dan industri bidang keahlian teknik mesin. Disertasi. tidak diterbitkan, Yogyakarta: Universitas NegeriYogyakarta

Walker, Robert J. (2008). Twelve characteristics of an effective teacher a longitudinal, qualitative, quasi-research study of inservice and pre-service teachers', educational Journal HORIZONS Fall, 61

Wong, H., \& Wong, R. (2005). How to be an effective teacher: the first days of school. Mountain View: Harry K. Wong Publications, Incorporated.

YPPTI. (April 2010). Reposisi dan reorientasi pendidikan kejuruan menjelang 2020. diambil pada 10 Oktober 2012 dari http://yppti.org/index.php?option=com content $\&$ view $=$ article $\&$ id $=48 \&$ Itemid $=$ $\underline{56}$. 